This is the version of the chapter accepted for publication in Badenoch, Nathan and Choksi, Nishaant, (eds.), Expressives in the South Asian Linguistic Area. Leiden: Brill, pp. 278-299. (Brill's Studies in South and Southwest Asian Languages, Volume: 13)

https://doi.org/10.1163/9789004439153_014

Accepted version downloaded from SOAS Research Online: http://eprints.soas.ac.uk/34576

\title{
EXPRESSIVES IN DUHUMBI ${ }^{1}$
}

By Timotheus Adrianus Bodt

Bern University Switzerland/Tezpur University India

This chapter describes expressives found in Duhumbi, a Tibeto-Burman language spoken by a mere 600 speakers in a single valley in West Kameng district in the western part of the Indian state of Arunachal Pradesh, close to the border with Tibet and Bhutan. Together with its sister language Khispi and the languages Sartang and Sherdukpen, Duhumbi forms a coherent sub-group within the 'Kho-Bwa cluster' (van Driem 2001: 473), called the Western Kho-Bwa languages (Bodt 2014; Lieberherr and Bodt 2017). For want of space, this chapter will not discuss much of the existing theory on expressives, and neither compare the Duhumbi expressives with expressives in genetically related languages or contact languages, but rather focus on the description of expressives in Duhumbi.

In Duhumbi, expressives have the following characteristics, which are generally found in expressives in other languages as well.

1. Duhumbi expressives are words, in that they are conventionalised items with a specific meaning (e.g. Dingemanse, 2012). Moreover, Duhumbi expressives form a separate word class (e.g. Patent 1998).

2. Duhumbi expressives are marked, and stand out from other words in Duhumbi, because they have at least a modified reduplicative structure (e.g. Dingemanse 2012, Osada 2008, Patent 1998).

3. Duhumbi expressives are iconic: they do not just describe the action, but depict it (e.g. Dingemanse 2012, Patent 1998), as a performance, including sound, movement, smell etc.

4. Duhumbi expressives depend on perceptual knowledge deriving from sensory perception (e.g. Dingemanse 2012).

\footnotetext{
${ }^{1}$ Parts of the content of this chapter I first presented as my inaugural PhD defence at Bern University on $29^{\text {th }}$ September 2017.
} 
5. Duhumbi expressives are extremely specific, in that their depiction that they invoke can only be applied to certain situations and not to others.

6. Duhumbi expressives often preserve conservative phonological features not preserved in other parts of speech.

7. Duhumbi expressives cannot be modified by any dependant morphemes.

8. Duhumbi expressives are considered a hallmark of eloquent speech, but at the same time their use is rapidly declining.

The following sections will discuss all these characteristics, which finally allows for a limitation as to which Duhumbi linguistic forms are considered expressives, and which are not. As will be shown, the Duhumbi word class of expressives, defined as 'a form class with semantic symbolism and distinct morphosyntactic properties' does not differentiate between 'expressives' in its broadest sense and 'ideophones', a subclass in which the symbolism is phonological, but on the other hand excludes 'onomatopoetics', ideophones in which the reference of the symbolism is purely acoustic (Diffloth 1976:263-264 and Emeneau 1980:7).

\section{DUHUMBI EXPRESSIVES ARE WORDS, FORMING A SEPARATE WORD CLASS.}

The expressives in Duhumbi are words, conventionalised items that carry a specific meaning. They are not reduplicated morphemes with a grammatical function, which also exist in Duhumbi, and neither are they mere nouns or interjections representing sound. Moreover, although they may be based on a combination of lexical words or roots, they are not simply repetitions of lexical words, such as repeated verbs. Most commonly, the basic unit of the reduplicated element has no meaning, with the exception of the 'elaborate expressions'. Unlike other languages (see, e.g. Diffloth 1980: 55-56), Duhumbi expressives are conventionalised: both their form and their meaning appear fixed, and all Duhumbi speakers will be able to visualise the picture depicted by the expressive. However, it is not clear whether this is because all Duhumbi expressives form an integral part of the lexicon and hence have a fixed meaning, or whether the sound iconicity of their individual phonemes and the combination of these phonemes embodies creates the same image among all speakers. 
In a clause or sentence, Duhumbi expressives are usually found in between a noun or noun phrase and its accompanying verb or verb phrase, which may also be a copula. Most expressives do not only modify the noun (as an adjective) or the verb (as an adverb), but modify the clause or sentence in its entirety. There is one sub-type of Duhumbi expressives, namely the 'elaborate expressions' that function most commonly as nouns (see also Patent 1998: 163 on a same observation from Lai).

Although the absolute number of expressives in Duhumbi may be less than in other languages, and also less than the absolute number of, say, lexical nouns or verbs, this may simply be due to the lack of description, and expressives do seem to constitute a considerable word class within the Duhumbi lexicon.

\section{DUHUMBI EXPRESSIVES HAVE A REDUPLICATIVE STRUCTURE}

The second characteristic of the Duhumbi expressives is that their syllabic structure is fully or modified reduplicated ${ }^{2}$. The expressives can consist of two, three, or four syllables, and can be further divided in several sub-types, based on whether nothing, a single consonant, the vowels, or entire syllables are modified. The reduplicative patterns can be schematically depicted as in (1), (2), (3a) and (3b), (4) and (5a) and (5b), using C for consonant, $\mathrm{V}$ for vowel, subscript numbers to indicate their position in the word, bold font for the modified part in the reduplication, square brackets to divide syllables, brackets to indicate optional consonants, and dashes to divide the reduplicated parts.

Bisyllabic:

(1) $\left[\mathrm{C}_{1} \mathrm{~V}_{1}\left(\mathrm{C}_{2}\right)\right]-\left[\mathrm{C}_{1} \mathrm{~V}_{1}\left(\mathrm{C}_{2}\right)\right]$, e.g. suysuy 'pleasant', said of the smell of, for example, rice, or a flower.

Trisyllabic:

(2) $\left[\mathrm{C}_{1} \mathrm{~V}_{1}\right]-\left[\mathrm{C}_{2} \mathrm{~V}_{1}\right]-\left[\mathrm{C}_{2} \mathrm{~V}_{1}\right]$, e.g. perere 'loudly', said of a continuous loud and often annoying noise like a chainsaw.

Quadrisyllabic:

\footnotetext{
2 Reduplicated expressive structures, similar to those found in Duhumbi, can also be found in the contact languages Tawang Monpa (own data), Tshangla (own data), the genetically related language Sherdukpen (Jacquesson 2015 and own data), as well as in Bodo ('twin words' in Bhatt 1968: 35), and in Lepcha (Dattamajumdar 2009). In the grammar of Tibetan, a reduplicated pattern is called ldab-tshig 'repeat word'.
} 
(3a) $\left[\mathrm{C}_{1} \mathrm{a}\right]\left[\mathrm{C}_{2} \mathrm{a}\left(\mathrm{C}_{3}\right)\right]-\left[\mathrm{C}_{1} \mathbf{o}\right]\left[\mathrm{C}_{2} \mathbf{o}\left(\mathrm{C}_{3}\right)\right]$, e.g. dapadopo, depicting either a person's physical handicap (such as missing or malfunctioning limbs), or a garbled manner of speaking (such as a speech deficiency of deaf-mute person or drunk).

(3b) $\left[\mathrm{C}_{1} \mathrm{a}\right]\left[\mathrm{C}_{2} \mathrm{a}\left(\mathrm{C}_{3}\right)\right]-\left[\mathrm{C}_{1} \mathbf{i}\right]\left[\mathrm{C}_{2} \mathbf{i}\left(\mathrm{C}_{3}\right)\right]$, e.g. tsakatsiki, depicting things that are 'small and miscellaneous'.

(4) $\left[\mathrm{C}_{1} \mathrm{~V}\left(\mathrm{C}_{2}\right)\right]\left[\mathrm{C}_{3} \mathrm{~V}\left(\mathrm{C}_{4}\right)\right]-\left[\mathrm{C}_{5} \mathrm{~V}\left(\mathrm{C}_{2}\right)\right]\left[\mathrm{C}_{3} \mathrm{~V}\left(\mathrm{C}_{4}\right)\right]$, e.g. bolocolo, which depicts an excess of something, such as, for example, servings of food and drinks offered to guests.

(5a) $\left[\mathrm{C}_{1} \mathrm{~V}_{1}\left(\mathrm{C}_{2}\right)\right]\left[\mathrm{C}_{3} \mathrm{~V}_{2}\left(\mathrm{C}_{4}\right)\right]-\left[\mathrm{C}_{5} \mathrm{~V}_{3}\left(\mathrm{C}_{6}\right)\right]\left[\mathrm{C}_{3} \mathrm{~V}_{2}\left(\mathrm{C}_{4}\right)\right]$, e.g. nakat ${ }^{h}$ eka, depicting a lingering manner of repeatedly halting and waiting on this side and on that side during movement towards goal.

(5b) $\left[\mathrm{C}_{1} \mathrm{~V}_{1}\left(\mathrm{C}_{2}\right)\right]\left[\mathrm{C}_{3} \mathrm{~V}_{2}\left(\mathrm{C}_{4}\right)\right]-\left[\mathrm{C}_{1} \mathrm{~V}_{1}\left(\mathrm{C}_{2}\right)\right]\left[\mathrm{C}_{5} \mathrm{~V}_{3}\left(\mathrm{C}_{6}\right)\right]$, e.g. $k^{h}$ orak $^{h}$ omp ${ }^{h} i$, depicting lame and crippled animate beings.

The various sub-types of Duhumbi expressives and their characteristics are discussed below.

(1) $\left[\mathrm{C}_{1} \mathrm{~V}_{1} \mathrm{C}_{2}\right]-\left[\mathrm{C}_{1} \mathrm{~V}_{1} \mathrm{C}_{2}\right]$

These expressives simply reduplicate the same syllable without modification. They always depict what are considered as 'positive' or 'neutral' actions, attributes or mannerisms, and never something that is considered as negative, bad or unwanted. They are often relatively easy to define and have a relatively limited applicability, most commonly functioning as adjectives, modifying a noun, and often occurring in copular clauses or sentences. Examples include doydoy, depicting a person or animal with a strong, well-built physique; $t^{h} o m t^{h} o m \sim t^{h} u m t^{h} u m$, depicting a place or space that is completely dark and lacking any visibility; and $t 6^{h} i p t 6{ }^{h} i p$ or sipcip, depicting, for example, clothes that are folded in a neat way. There are a few examples where there is phonological alternation between a bilabial plosive and a nasal coda consonant, such as dopdom depicting, for example, sugarcane that is succulent; or tseptsen, depicting the pointedness of, for example, a knife or a pencil: this coda alternation is non-distinct. These expressives are considered highly iconic, and, for a Duhumbi speaker, immediately paint a vivid image: when someone says the sugarcane is dopdom, it invokes an image of the 
sound, smell, taste and structure of a thick stick of sugarcane, full of sweet juice that splashes, seeps and drips out as soon as the outer cover is peeled off with the teeth and the inner fibres are crushed as they are chewed upon.

The previous examples depict an attribute or an action, but some other examples of these expressives refer more to a certain manner, such as $k^{h} u s k^{h} u s$ 'up and down', said of, for example, an affirmative nod with the head; and poypon 'engaged', said of, for example, a lively talk or discussion. The latter expressives have slowly come to describe the entire action as a noun, with $k^{h} u s k^{h} u s$ usually referring to 'an affirmative nod with the head' and

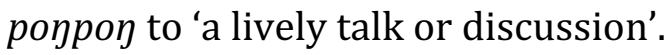

Characteristic of this type of expressives is that they often occur in combination with the verb le $\{d a\}$ 'to do', and then describe the action, as in wat ${ }^{h}{ }^{h} i p t 6{ }^{h}$ ip le-da clothes ${ }^{h}{ }^{h} i p t{ }{ }^{h} i p$ do-ADV 'making the clothes folded up neatly' and war-bak poppoy le-da dau-ni 3PL-PL poypoy do-ADV stay-PRET 'all of them were having an engaged conversation'. Dingemanse (2012: 657) also noted that 'Ideophones are often introduced using quotative markers or "say" or "do" verbs, emphasizing their depictive-performative nature'. It may be thus be surmised that these expressives started out as pure adjectives, and obtain a more adverbial status through their combination with forms of the verb le $\{\mathrm{da}\}$ 'to do.

An example from a Duhumbi mani tam 'riddle', which cryptically describes an item of every day use to test the competitor's cleverness, can be found in (1). The expressive birbir depicts a flattening movement, like rolling a ball of dough to make flat pancake, or, in this case, the movement of the jardouy, two sticks connected with a hinge, with one stick held in hand, and the other stick slung in sky and smacked on pile of dry finger millet to thresh it. The expressive is derived from the verb bir $\{\mathrm{ta}\}$ 'to flatten'.

(1) Sala birbir, namla birbir abe insena?

$\begin{array}{lllll}\text { sa-la } & \text { birbir } & \text { namt }{ }^{h} \text { uy-la } & \text { birbir } & \text { abe in-se=na } \\ \text { earth-LOC } & \text { flattening } & \text { sky-LOC } & \text { flattening what say-COND=CONF }\end{array}$

'What is flattening the earth, flattening the sky?'

(2) $\left[\mathrm{C}_{1} \mathrm{~V}_{1}\right]-\left[\mathrm{C}_{2} \mathrm{~V}_{1}\right]-\left[\mathrm{C}_{2} \mathrm{~V}_{1}\right]$ 
Expressives with the trisyllabic syllable shape have a second and third syllable in which the onset consonant is modified. They depict both the attribute of the object of the noun phrase, and the manner of the action of the verb phrase that they modify in a clause or sentence. These expressives always have a durative or continuous implication, and are hence often encountered with verbal forms with the progressive aspect in -dbu 'stay'. Examples include jiriri 'rapidly', which can depict the rapid, continuous and progressive movement of the sun across sky at dusk, of the sunlight over a landscape at dusk, or of a walking person or his shadow against the background of a landscape, and derere $\sim$ dororo, which depicts a vehemently occurring involatile movement of an object or person, such as the shiver of a person suffering from fever, trembling of fear, or the shaking of an earthquake.

An example of this type of expressives can be found in (2). The expressive dololo creates the image of smoke appearing on a plot of land in big, undulating, billowing clouds, indicating inhabitation at the place. The smoke could, for example, be caused by the burning of a wood fire in the house, by the burning of incense, or by the burning and clearing of shifting cultivation land. The expressive dololo depicts the entire scene, and is not just an attribute of the smoke itself, nor the way how it appears.

(2) Sa udi hink ${ }^{h}$, buk $k^{h}$ ray dololo getckude?lo?.

$\begin{array}{llllll}s a & \text { udi } & h i n-k^{h} o & b u k^{h} u=r a y & \text { dololo } & \text { cet-dbu-de?=olo? } \\ \text { place } & \text { good } & \text { one-LOC } & \text { smoke=EMPH } & \text { dololo } & \text { exit-stay-PRES=then }\end{array}$

'On a good plot of land, even the smoke is appearing in big, billowing clouds.'

(3a) $\left[\mathrm{C}_{1} \mathrm{a}\right]\left[\mathrm{C}_{2} \mathrm{a}\left(\mathrm{C}_{3}\right)\right]-\left[\mathrm{C}_{1} \mathbf{o}\right]\left[\mathrm{C}_{2} \mathbf{o}\left(\mathrm{C}_{3}\right)\right]$

In this type of expressives, two syllables are reduplicated, with the vowel /a/ in the first two syllables changing to vowel /o/ in the second two. These expressives depict something disorganised, chaotic, messy, and in general negative. Often, a single expressive can have two distinct, but nonetheless somehow semantically related meanings, as examples (3) and (4) show.

(3) woj yak balabolo hawde?

woj gak balabolo haw-de? 
3SG speech balabolo speak-PRES

'(s)he speaks in an insincere manner.'

(4) t6 $^{h}$ ura balabolo be?

$$
\begin{array}{ll}
\text { t6 } & \\
\text { cheese } & \text { balabola }
\end{array}
$$

'The cheese is over-ripe.'

An example from the corpus includes (5). This is from a prediction text by the last practicing bonpo 'local religious practitioner', who passed away early 2016. The expressive dzakadzoko is placed in between the subject and the predicate of the sentence, modifying both, and creating a lively image of a contagious disease that causes diarrhoea, pus-containing blisters, boils and wounds, sputum-filled cough, running noses, teary eyes, fever and sweating, and moreover, spreading rapidly from person to person, from house to house, and from village to village.

(5) Rimt6 $^{h}$ e, rimt6 ${ }^{h}$ e dzakadzoko $p^{h} e^{\text {ett }}{ }^{h}$ ello?.

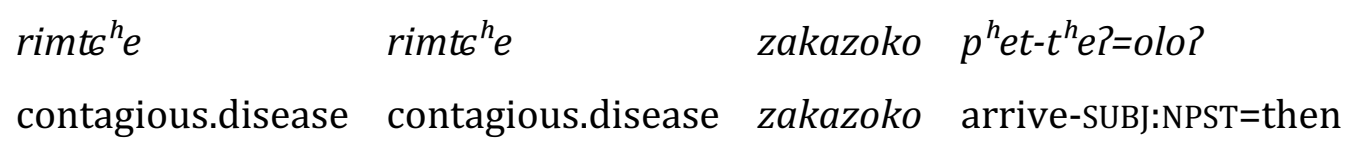

'The contagious disease, the messy contagious disease would arrive.'

(3b) $\left[\mathrm{C}_{1} \mathrm{a}\right]\left[\mathrm{C}_{2} \mathrm{a}\left(\mathrm{C}_{3}\right)\right]-\left[\mathrm{C}_{1} \mathbf{i}\right]\left[\mathrm{C}_{2} \mathbf{i}\left(\mathrm{C}_{3}\right)\right]$

In this type of expressives, two syllables are reduplicated, with the vowel /a/ in the first two syllables changing to vowel /i/ in the second two. These expressives depict something diminutive, small, irrelevant or useless. An example is tsapatsipi in shreds, in bits and pieces', derived from the verb tsap $\{d a\}$ 'to chop in pieces'. Another example can be found in (6), depicting the beeswax trade that was conducted occasionally, rather than often or constantly.

(6) $T^{h}$ e brukpabakp ${ }^{h}$ unnit ${ }^{h} e$ ? $s^{h}$ oy le, rup lahan man, leda, raparipi ose leda manbale ho?.

$\begin{array}{llll}t^{h} e & \text { brukpa-bak- } p^{h} u n-n i=t^{h} e ? & t^{h} \text { on le, rup lahan man, } \\ \text { the.other.side } & \text { Bhutanese-PL-etc.- } & \text { trade do money some obtain } \\ & \text { PAT=ADD } & & \end{array}$




$\begin{array}{llllll}l e-d a, & \text { raparipi } & \text { ose } & l e-d a, & \text { man-ba=le } & \text { ho? } \\ \text { do-ADV } & \text { raparipi } & \text { like.that } & \text { do-ADV } & \text { obtain-NOM=COP2 } & \text { now }\end{array}$

'Trading (the beeswax) to all the various Bhutanese yonder too, getting some money, doing it, occasionally doing like that, (in the distant past the villagers) obtained (money).'

There are a few attestations of expressives with the syllabic shape $\left[\mathrm{C}_{1} \mathrm{a}\right]\left[\mathrm{C}_{2} \mathrm{a}\right]-\left[\mathrm{C}_{1} \mathbf{u}\right]\left[\mathrm{C}_{2} \mathbf{u}\right]$, for example $t 6^{h} \operatorname{arat}^{h} u r u$, depicting, for example, a small, thin line of smoke rising straight up from a chimney or fire. These expressives are rare, often have good cognates in the contact language Dirang Tshangla, do not seem to have a shared semantic connotation, and are sometimes mentioned as alternatives of expressives of shape $\left[\mathrm{C}_{1} \mathrm{a}\right]\left[\mathrm{C}_{2} \mathrm{a}\right]-$ $\left[\mathrm{C}_{1} \mathbf{i}\right]\left[\mathrm{C}_{2} \mathbf{i}\right]$. Hence, they may be of a borrowed origin. For example, the expressive satasiti, which, for example, depicts a thief stealing small and insignificant things from houses, has also been attested to occur as satasutu.

The final three types of expressives are what have also been called as 'elaborate expressions' (e.g. Patent 1998: 163 for Lai, Haas 1964 for Thai, Jaisser 1990: 160 and Mortensen 2003 for Hmong, Gerner 2004, 2005 for the Tai-Kadai language Dong and Vittrant 2014 for Burmese and more recently Lieberherr 2017: 138, 269-272 for Bulu Puroik), and are considered typical of East and Southeast Asian languages. Matisoff (1973: 81) described them as a 'compound containing four (usually monosyllabic) elements, of which either the first and third or the second and fourth are identical (A-BA-C or A-B-C-B) [and that] characteristically convey a rather formal or elegant impression'. These expressives depict an action in its entirety, painting a vivid picture of what happens.

\section{(4) $\left[\mathrm{C}_{1} \mathrm{~V}\left(\mathrm{C}_{2}\right)\right]\left[\mathrm{C}_{3} \mathrm{~V}\left(\mathrm{C}_{4}\right)\right]-\left[\mathrm{C}_{5} \mathrm{~V}\left(\mathrm{C}_{2}\right)\right]\left[\mathrm{C}_{3} \mathrm{~V}\left(\mathrm{C}_{4}\right)\right]$}

In the first type of elaborate expression, only the onset of the first reduplicated syllable is modified. An example is $\operatorname{murgutc}^{h}{ }^{u r g u}$, which depicts a storm, characterised by strong gales of wind, heavy rainfall or hail. Another example can be found in (7), where ts ${ }^{h}$ alaynalay depicts the way in which something is dispersed, scattered and spread out over large area due to the action of some agent, such as, for example, when someone trips and lets a basket of grains fall on floor, or, as in this example, the people of Duhum after a raid by the Miji people. 


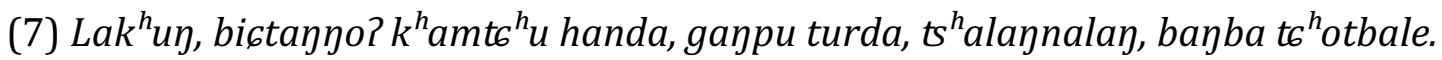

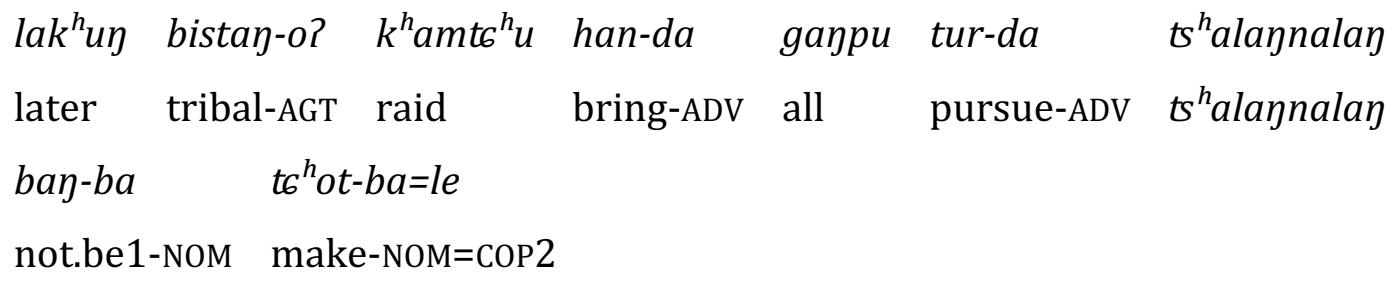

'Later, the Miji tribal people, bringing a raid, chasing everyone, made (all) disappear in every direction.

(5a) $\left[\mathrm{C}_{1} \mathrm{~V}_{1}\left(\mathrm{C}_{2}\right)\right]\left[\mathrm{C}_{3} \mathrm{~V}_{2}\left(\mathrm{C}_{4}\right)\right]-\left[\mathbf{C}_{5} \mathbf{V}_{3}\left(\mathbf{C}_{6}\right)\right]\left[\mathrm{C}_{3} \mathrm{~V}_{2}\left(\mathrm{C}_{4}\right)\right]$

In the second type of elaborate expressions, the first syllable of the reduplicated part is modified in its entirety. An example is lacarluy6ar, which depicts the act of making extended journeys by crossing mountains and valleys and is derived from the nouns $l a$ 'mountain pass', lungpa 'valley' and the verb car $\{d a\}$ 'to cross over, to pass through'. Another example can be found in (8), in which bints ${ }^{h} u p k e j t s^{h} u p$ depicts the act of nicknaming, and is derived from the noun bin 'name', and the verbs kej $\{d a\}$ 'to place' and $t^{h} u p\{d a\}$ 'to acquire'. In combination with verb le $\{d a\}$ 'to do' this depicts the action of giving nicknames.

(8) Duhumbi Bowra insena, bigts ${ }^{h}$ upkejt $^{h}$ up lederbejlo?? Bin ts ${ }^{h} u p k^{h}$ enna?bak le.

\begin{tabular}{|c|c|c|}
\hline duhumbi & bowra & bints ${ }^{h}$ pkejts $^{h} u p$ \\
\hline Duhumbi & cut.bamboo.stalks & say-COND $=\mathrm{CONF} \quad$ bints $^{h} u p k e j t s^{h} u p$ \\
\hline$l e-d e ?=b e$ & $=a j=o l o ?$ & $t s^{h} u p-k^{h} e n-a P-b a k$ \\
\hline $0-P R$ & OP1=ok=then name & N-PL $\quad$ COP2 \\
\hline
\end{tabular}

'Duhumbi Bowra means to say: isn't it that so that (people) give nicknames? It is all those acquired names'.

(5b) $\left[\mathrm{C}_{1} \mathrm{~V}_{1}\left(\mathrm{C}_{2}\right)\right]\left[\mathrm{C}_{3} \mathrm{~V}_{2}\left(\mathrm{C}_{4}\right)\right]-\left[\mathrm{C}_{1} \mathrm{~V}_{1}\left(\mathrm{C}_{2}\right)\right]\left[\mathrm{C}_{5} \mathbf{V}_{3}\left(\mathrm{C}_{6}\right)\right]$

The final type of Duhumbi expressives are those in which the second syllable of the reduplicated part is modified in its entirety. An example includes the famous nickname of the Duhumbi people, bowrabowki, based on the noun bowra 'cut bamboo stalk' and referring to the practice of the Duhumbi people to collect bamboo stalks and make various products from it for barter and sale. Another example is $t 6^{h} e p l a t c^{h} e p l i$, which 
depicts pieces and patches of cloth of different sizes and is derived from the noun $t 6^{h} e p l a$ 'patch of cloth'.

\section{DUHUMBI EXPRESSIVES ARE ICONIC.}

As Diffloth (1980: 50) indicated, expressives are iconic, and every pattern that is found in expressive phonology but not in prosaic phonology will be of iconic value. Till now, the iconicity of the Duhumbi expressives has not yet been fully examined, largely because only a small subset of all Duhumbi expressives has been observed and described. Hence, minimal pairs of expressives with different onset and rhyme combinations could not be analysed in detail. Nonetheless, particularly the basic semantic connotation between the quadri-syllabic expressives of the shape $\left[\mathrm{C}_{1} \mathrm{a}\right]\left[\mathrm{C}_{2} \mathrm{a}\right]-\left[\mathrm{C}_{1} \mathbf{i}\right]\left[\mathrm{C}_{2} \mathbf{i}\right]$ and those of the shape $\left[\mathrm{C}_{1} \mathrm{a}\right]\left[\mathrm{C}_{2} \mathrm{a}\right]-\left[\mathrm{C}_{1} \mathbf{0}\right]\left[\mathrm{C}_{2} \mathbf{o}\right]$ clearly indicates the acoustic symbolism represented in them. The open vowel /i/ [i] is realised in the front of mouth, is short in length, and does not rely on opening the mouth much. The open vowel /o/ [э:], on the other hand is realised from the back of the throat, opens the mouth and is long. This is reflected in their semantic connotations: there are numerous examples that illustrate how they differ between 'small, insignificant' versus 'chaotic, disorganised', such as (1a) and (1b) or (2a) and (2b).

(1a) zapazipi, depicting, for example, instant noodles in a packet that are made into small crumbles by hand.

(1b) zapazopo, depicting, for example, the chillies in a winnowing tray being of various sizes and being dried to various degrees so that they cannot easily be pulverised by hand.

(2a) malakmilik, depicting, for example, water that is released into the paddy field and mixed with mud, but the resulting mixture is too thick, in that it contains too little water, it $\quad$ is then said $k^{h}$ ow malakmilik be? 'the water is malakmilik'.

(2b) malakmolok, depicting, for example, a snake that was beaten daradiri (cf. example (9)): the uncoordinated, spasmed, wriggling movements of the snake, that does not die, but can neither raise itself up or move away, is called as malakmolok.

Although Diffloth (1994: 107) also identified exceptions, he noted that 'it is often said that if vowel quality is used for size symbolism, [i] will symbolize smallness, and the lower 
vowels, especially [a], will symbolize largeness, with degrees in between'. A similar sound symbolism for the vowel /i/ and /a/ /u/ was observed in other languages (e.g. Osada 2008, Patent 1998: 161 and 194-195), but the sound symbolism of the vowel /o/ as described here for Duhumbi has perhaps not been reported yet.

A larger corpus of conscientiously described and defined Duhumbi expressives, both from natural speech and elicitation, will probably reveal the iconicity of phonological distinctions - for example, between voiced and unvoiced onsets, between open and closed syllables, between plosives, nasal and fricative onsets etc. - in more detail. Further comparison with similarly structured expressives from languages such as Tibetan, Lepcha, Boḍo, Tshangla, Tawang Monpa and Sherdukpen, will undoubtedly shed more light on the deeper connection between sound and meaning in the Tibeto-Burman languages of this region.

\section{DUHUMBI EXPRESSIVES RELY ON SENSORY PERCEPTION.}

Duhumbi expressives do not simply describe a certain action, but they depict it, in its entirety, as a 'package' of sounds, sights, smells, movements, and other features, providing vivid imagery 'colour' or, as Patent (1998) termed it 'flavour'. The additional sensory imagery may be of a visual (related to appearance), audible (related to sound), olfactory (related to smell), gustatory (related to taste), haptic (related to feeling) or social (related to social behaviour) nature. The, often lengthy, descriptions of expressives attest to this, as do the articulation and gestures of the people who use them. Although this is hard to illustrate without video and sound, example (9) gives an impression. Without any fault or mistake committed by her, the junior queen is given a beating daradiri by the senior queen and the king. For a Duhumbi audience, this invokes a scene of a merciless, excruciatingly harsh and painful beating, with the queen crunching up to a small size to avoid getting hurt, protecting her head with her arms, with those beating using all their force and strength to hurt her as much as they can. As repetition is a common Duhumbi stylistic tool for emphasis, the strength of the expressive is further augmented by its repetition. The scene invokes immediate sympathy and compassion with the junior queen, and a negative feeling towards those who administer the beating.

(8) Dapda daradiri daradiri Gida, $k^{h} u 6 a \eta$ gappu $p^{h}$ okda, makda, leloybe. 


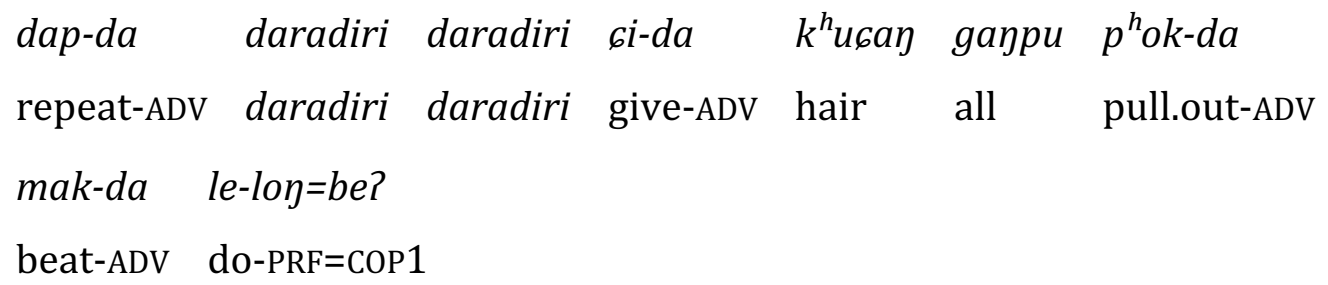

'Again, (the king and senior queen) had done it, giving (the junior queen) (a beating) daradiri, pulling out all the hair, beating (her).'

A similar scene could never have been achieved with a general adverb such as jamts ${ }^{h}$ en 'very much'. The right expressive in the right context adds the 'spice' that makes the audience listen to the narrative in admiration and awe, or adds the 'spice' to an argument to convince the audience of one's point. There may also be intricate relations with grammatical systems of evidentiality and interactional devices like reported speech (Dingemanse 2012: 664-666), not only in personal narratives and stories, but also in everyday conversations.

\section{DUHUMBI EXPRESSIVES ARE SPECIFIC.}

Another characteristic of Duhumbi expressives is that they are extremely specific. Although they can be used to depict several, usually somehow 'related' things, the semantic nuances between various expressives is often very fine. The specificity of the iconicity embodied in the Duhumbi expressives can best be illustrated with examples.

Duhumbi speakers, when asked to define a given expressive in their own language, often resort to providing lengthy depictions of instances when the expressive can be used, using facial expressions, gestures, or even items at hand to depict the scene, and often provide depictions of scenes where not this expressive, but another expressive, is more suitable, as also noted by Diffloth (1972: 441).

Example (1) explains the process of making tsopi, a porridge of maize flour, when asked to describe the meaning of the expressive bekabeka.

(1) When mixing an amount of water in a pile of maize flour with a spoon and the amount of water is still more and the flour has not yet completely dissolved, this is called as tsopitsopi, i.e. mej6in $p^{h} o j-k^{h} o k^{h} o w h u k-d a, k o j-d a$, tsopitsopi cet-dbu-le maize flour-LOC 
water pour-ADV mix-adv tsopitsopi exit-stay-COP2 'pouring water in maize flour, mixing it, it will be coming out tsopitsopi'. If continuing to mix till a smooth paste results, this is called as bakaboko, i.e. mejcin $p^{h} o j-k^{h} o k^{h} o w$ huk-da bakaboko koj-da maize flour-LOC water pour-ADV bakaboko mix-ADV 'pouring water in maize flour and mixing it (till) bakaboko'. When water has been brought to a rolling boil over a fire, boga 'bubbles' appearing and lots of łaypa 'steam' evaporating, this is described as bololo, e.g. khow bololo chow-de? water bololo boil-PRES 'the water boils bololo'. When the maize paste is then slowly poured and stirred into the boiling water, and the water is evaporating, changing the consistency to a porridge, with bubbles surfacing and splashing open, releasing puffs of hot air, this is described as bekabeka, i.e. tsopi bekabeka t6 ${ }^{h}$ ow-de? tsopi bekabeka boil-PRES 'the tsopi is boiling bekabeka'. When then the water is almost completely evaporated, with bubbles from the porridge now forming less and less frequent, less steam evaporating, and the porridge may get burnt to the cooking vessel, this is described as $t 6^{h}{ }$ plaptc $^{h}$ oplop, i.e., tsopi don-ma-ba- $k^{h}$ o t6 ${ }^{h}$ aplaptc ${ }^{h}$ oplop le-de? tsopi cook-finish-NOM-LOC $t_{6}{ }^{h}$ aplapt $^{h}$ oplop do-PRES 'when finishing cooking, the tsopi does like t6 ${ }^{h}$ aplapt6 ${ }^{h}$ oplop'.

Duhumbi speakers may also use an expressive as the antonym of another expressive to illustrate its meaning. For example, to explain the meaning of raykorayko in (10), the speaker said that it is the opposite of ${ }^{h}{ }^{h}{ }^{i p t 6}{ }^{h} i p$.

(10) raykaroyko insena, siy jayna? mej t6 ${ }^{h} i p t{ }^{h}{ }^{h}$ ip baleba leda, $t^{h}$ ejta tos t6 ${ }^{h}$ ojta tostaleda, ...

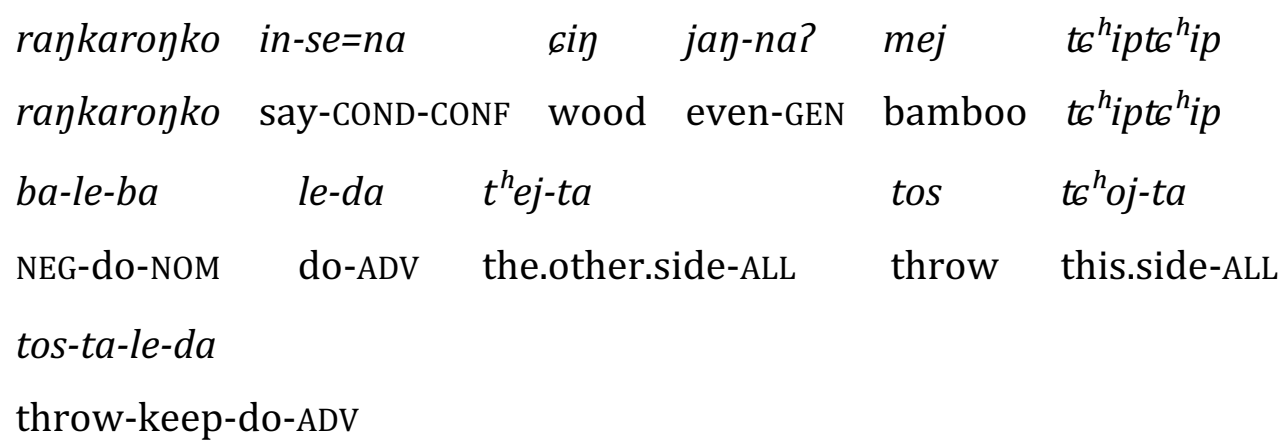

'raykaroyko means, not keeping fire wood or bamboo sticks neatly arranged, but keeping them thrown to this side and that side'.

Duhumbi has a rich repertoire of expressives that depict the negative behaviour of people, as examples (1) - (8) illustrate. Why there are no expressives depicting the 
positive behaviour of people is not known, and may well be of a socio-linguistic and cultural nature.

(1) nakanoko, depicting a person who refuses to get up in the morning and just stays idle the whole day.

(2) $t s^{h} a_{m a t}{ }^{h}$ omo, depicting a person who behaves in a general disorganised manner.

(3) jakajoko, depicting a person who feels and moves in a weak and uncontrolled manner because of a serious, dilapidating illness.

(4) $t^{h}{ }^{h}$ rat6 $^{h}$ oro, depicting a person who feels and moves around in a weak and uncontrolled manner, stumbling here and there, because of lack of energy or a hangover. (5) nasanoso, depicting a person who is (acting like a drunk), with loud and incoherent talking, and picking up fights and quarrels

(6) jakajiki, depicting a person who is acting in an agitated or fussy manner, usually about what others consider a trivial issue.

(7) zakaziki, depicting a person who sits around idly day after day because he does not know what to do and how to speak properly.

(8) jakaniki, depicting a person who gets hurt or insulted very easily, is complaintive in nature, and is never satisfied with anything (a 'softy') ${ }^{3}$.

Finally, the specificity of Duhumbi expressives can be illustrated by the fact that, unlike the Duhumbi adjectives or adverbs, Duhumbi expressives usually occur in combination with only a few combinations of nouns and verbs - oftentimes, just a single one (see also Patent, 1998: 157).

\section{DUHUMBI EXPRESSIVES CONSERVATIVELY RETAIN PHONOLOGICAL FEATURES.}

As Diffloth (1980: 57) already indicated, expressives do not commonly use phonetic material that does not occur in the prosaic part of the lexicon, and as Dingemanse (2012: 657) also wrote, they just use it in a different way. But perhaps due to their relatively low usage frequency, Duhumbi expressives tend to preserve phonological features that are less well preserved in other parts of speech, which makes expressives interesting from a historical comparative perspective. Examples are primarily the rhotic onset clusters /kr-

\footnotetext{
${ }^{3}$ Also used to describe, for example, clothes that are soft in feeling.
} 
, khr-, gr-/ and /pr-, phr-, br-/. Examples include $k^{h}{ }^{r i p} k^{h}$ rip, depicting a blink or wink of the eye and related to the noun-verb compound $k^{h} u m k^{h}$ rip $\{d a\}$ 'to blink they eye', and bratabrutu, depicting something that is done in bits and pieces. However, comparative evidence from contact languages shows there are clear cognates, such as Tawang Monpa meloy $k^{h}$ rip 'to blink the eye' and Dirang Tshangla bratabrutu, depicting something that is done in bits and pieces. This, and other evidence of cognates of lexemes with these onset clusters in the contact languages, may indicate that these clusters were borrowed together with the lexemes that contain them.

Other examples of the conservative retention of the rare onset clusters in the expressives can be found in examples (1), (2) and (3).

(1) $k^{h}$ rapak $^{h}$ ropo, depicting part of the vegetables in a curry not being properly cooked, whereas most of them are. This occurs often when cooking 'hard' vegetables like potato or radish together with 'soft' vegetables like eggplant, green leaves or beans by putting them in the boiling water at the same time, instead of first boiling the hard vegetables and then adding the soft ones.

(2) krapakripi, said of, for example, small pieces of bark, mosses and wood that remain after clearing the big pieces of fire wood out of the (temporary or permanent) storage place, or after the fire wood brought near the fireplace has been burnt.

(3) grapagrupu, said of, for example, chips or something else to eat which was kept in a plastic bag and has become crushed into small pieces due to transportation or storage.

\section{DUHUMBI EXPRESSIVES ARE AVERSIVE TO MORPHOLOGICAL MODIFICATION.}

Unlike other nominal and nominalised verbal parts of speech in Duhumbi, the expressives cannot be modified by dependant morphemes. The expressives lack any of the criteria that identify Duhumbi adverbs and adjectives, such as the native adjective prefix $u-/ o$-, the deverbal adjective suffixes $-b a /-p a$ NOM or $-k^{h} e n-n a ?$ AGN-GEN, the adverbal suffix $d a /$-ta ADV, or loan affixes such as - $b u$ and -mo. Expressives cannot be modified by the superlative and comparative degree markers: -shok COMP and -thakpa SUPERL. Unlike any other part of speech, expressives have not been attested to be modified by discourse 
clitics such as emphatic =ray EMPH, contrastive focus clitic $=n a$ CONF, general focus clitic $=t a$ FOC or additive focus clitic $=t^{h} e$ ADD. Whether such modification is possible in theory is ambiguous, and elicitation has hitherto not provided a conclusive answer. In common with expressives in most other languages, Duhumbi expressives have not been attested in negative phrases, clauses and sentences (Diffloth 1972: 444 and fn. 4 on 445). For example, they cannot be modified by the negative prefix $b a-N E G$, and neither do they occur in combination with forms of the negative copular verb bay 'to be not'.

\section{DUHUMBI EXPRESSIVES AS RAPIDLY DECLINING HALLMARK OF ELOQUENT SPEECH.}

In Duhumbi, the prolific and correct use of expressives is considered the hallmark of an eloquent speaker. Young, non-mother tongue or inexperienced speakers often make mistakes in their use or avoid their use completely. But due to their very specific form and meaning, the expressives are rapidly replaced by other linguistic forms, making them one of the most threatened grammatical features in the language. Hence, there is an urgent need to document and describe expressives in Duhumbi, and indeed in many other languages. This is, however, not an easy task, as they are notoriously difficult to observe through elicitation (Diffloth 1972: 440 and Diffloth 2001: 267, Patent 1998: 158-159) and mostly occur in engaged natural speech and narratives. Moreover, it is very difficult to correctly, shortly and meaningfully define or describe the minute semantic distinctions of expressives in other languages (Diffloth 1972: 441).

\section{REDUPLICATED STRUCTURES IN DUHUMBI THAT ARE NOT EXPRESSIVES}

The previous characteristics allow for the exclusion of several Duhumbi linguistic forms that also have a full or modified reduplicative structure.

The characteristic that Duhumbi expressives are words excludes reduplicated Duhumbi morphemes such as -sarsar 'about to' and $-t_{6}{ }^{h}$ okt6 ${ }^{h} o k$ 'ready to'. This characteristic also excludes onomatopoeic interjections such as haha 'sound of someone laughing'; kawkaw 'sound of a yelping or barking dog'; hawhaw 'threatening sound of a barking dog'; and hrawhraw 'deep threatening sound of a big barking dog (mastiff/nomad's guard dog)'. Although being reduplicative in structure, onomatopoeic nouns such as horhor 'a snore' or $p^{h} i w p^{h} i w \sim p s i w p s i w \sim$ sisi 'a whistle' are excluded from the expressives, because they belong to a different part of speech and because they do not depict an entire image but 
just mimic a certain sound. An interesting example of this is the bird 'green-backed tit', which has two names, one a rendering of the sound it makes in summer, $p^{h} i p^{h} i n$, and the

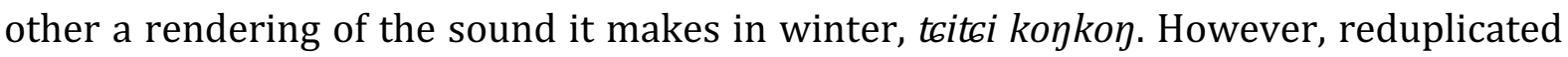
forms that depict a scene that is accompanied by a characteristic sound on which the expressive is largely based, such as 6owa6owa, depicting the current in a fast flowing, swollen river, or the waves on a large expanse of water, are considered as expressives.

The fact that they belong to another word class and are most commonly onomatopoeic in nature also excludes reduplicative nouns of the syllabic shape $\left[\mathrm{C}_{1} \mathrm{~V}_{1}\left(\mathrm{C}_{2}\right)\right]-\left[\mathrm{C}_{1} \mathrm{~V}_{1}\left(\mathrm{C}_{2}\right)\right]-$ [pa $\sim \mathrm{ba} \sim \mathrm{ma}$ ], with the last syllable being one of the allomorphs of the common Duhumbi nominaliser - $p a$ NOM. These reduplicative nouns mainly occur as names of insects that represent the characteristic sound that they make, such as rereba 'cicada' or tektekpa 'grasshopper'.

Expressives in Duhumbi also exclude unmodified repetitions of lexical words in the form of $\left[\mathrm{C}_{1} \mathrm{~V}_{1}\right]\left[\mathrm{C}_{2} \mathrm{~V}_{2}\right]-\left[\mathrm{C}_{1} \mathrm{~V}_{1}\right]\left[\mathrm{C}_{2} \mathrm{~V}_{2}\right]$, even when these are pronounced as a single intonation unit, such as nakanaka 'various', said of objects; hokohoko 'again and again, repetitively', said of actions; and ta?data?da 'equal', said of the size or height of people or objects. Repetition is a common Duhumbi stylistic tool for emphasis, and these adverbs and adjectives have as lexical sources Written Tibetan adjective sna-kha 'of different types, various', the Duhumbi verb ta? $\{d a\}$ 'to be equal', and the Duhumbi adverb ho?ko 'now'. These words lack the iconicity and the sensory basis of expressives.

Finally, excluded from the Duhumbi expressives are motherese nouns, such as tutu 'vagina', and nunu 'milk; breast'. These nouns, used to talk to small infants about food or taboo items, are most commonly reduplications of the original nouns, i.e. $t^{h} u$ 'vagina' and $n u$ 'milk; breast', and even when they are not, such as in the case of koko 'egg', they still belong to the word class of nouns, and are not iconic in nature to the same degree as the Duhumbi expressives.

Finally, unlike what has been described for other languages as psycho-collocations (Matisoff 1986, and various examples from Southeast Asia can be found in Vittrant 2014), i.e. polymorphemic expressions that make an explicit reference to body parts or organs 
as the locus of emotions or psychological states, are not considered expressives in Duhumbi. Structures such as buktum le $\{d a\}$ waist-do 'to palpitate' are analysed as nounverb compounds. They do not have any special morphophonological shape, and there is no overt 'colour' added to the composite meaning, even though this meaning cannot be directly derived from the individual compounds. In addition, most psycho-collocations in Duhumbi, especially those expressing more complex emotions, feelings and mental states, are of a clear borrowed origin. More basic bodily functions and feelings are described with native lexemes, such as intransitive verbs or noun-verb compounds.

As can be seen, the approach taken to Duhumbi expressives here is more limited than other approaches, such as in Dingemanse (2012: 663), where onomatopoeia (i.e. expressives/ideophones describing sound) are considered the first level in an implicational hierarchy. From this same hierarchy, it becomes apparent that the last level, inner feelings and cognitive states, are also not depicted by expressives in Duhumbi, but all other levels, sound (as a depiction, not a description), movement, visual patterns and others sensory perceptions, are all covered by expressives.

\section{GLOSSARY}

$\begin{array}{llll}\text { gloss } & \text { description } & \text { gloss } & \text { description } \\ \text { ADD } & \text { additive focus } & \text { FOC } & \text { focus } \\ \text { ADV } & \text { adverbialiser } & \text { GEN } & \text { genitive } \\ \text { AGN } & \text { agent nominaliser } & \text { LOC } & \text { locative } \\ \text { AGT } & \text { agent } & \text { NEG } & \text { negative } \\ \text { C } & \text { consonant } & \text { NOM } & \text { nominaliser } \\ \text { COMP } & \text { comparative degree } & \text { PAT } & \text { patient } \\ \text { COND } & \text { conditional } & \text { PL } & \text { plural } \\ \text { CONF } & \text { contrastive focus } & \text { PRES } & \text { present } \\ \text { COP1 } & \text { copula } & \text { SUBJ:NPST } & \text { non-past subjunctive } \\ \text { COP2 } & \text { copula } & \text { SUPERL } & \text { superlative degree } \\ \text { EMPH } & \text { emphatic } & \text { V } & \text { vowel }\end{array}$

\section{REFERENCES}

Bhat, D. N. Shankara. 1968. Boro Vocabulary. Poona: Deccan College. 
Dattamajumdar, Satarupa. 2009. Reduplicated expressives in Lepcha. The Buckingham Journal of Language and Linguistics Vol. 2: 19-26.

Diffloth, Gérard. 1972. Notes on expressive meaning. Papers from the Eighth Regional Meeting of the Chicago Linguistics Society. Chicago: Chicago Linguistics Society, pp. 440-447.

Diffloth, Gérard. 1980. Expressive phonology and prosaic phonology in Mon-Khmer. In Theraphan L. Thongkum (ed.). Studies in Mon-Khmer and Thai Phonology and Phonetics in Honor of E. Henderson: 49-59. Bangkok: Chulalongkorn University Press.

Diffloth, Gérard. 1994. i: big, a: small. In: Leanne Hinton, Johanna Nichols and John Ohala (eds.). Sound Symbolism: 107-114. Cambridge: Cambridge University Press.

Diffloth, Gérard. 2001. Les expressifs de Surin et où cela conduit. Le Bulletin de l'École française d'Extrême-Orient 88: 261-269.

Dingemanse, Mark. 2012. Advances in the Cross-Linguistic Study of Ideophones. Language and Linguistics Compass 6/10: 654-672.

van Driem, George L. 2001. Languages of the Himalayas - An Ethnolinguistic Handbook of the Greater Himalayan Region. Vol. 2. Leiden: Brill.

Emeneau, Murray B. 1980. Language and Linguistic Area. Stanford: Stanford University Press.

Gerner, Matthias. 2004. Expressives in Kam (Dong): a study of sign typology (part I). Cahiers de Linguistique d'Asie Orientale 33(2): 159-202.

Gerner, Matthias. 2005. Expressives in Kam (Dong): a study of sign typology (part II). Cahiers de Linguistique d'Asie Orientale 34(1): 25-67.

Haas, Mary R. 1964. Thai-English student's dictionary. Stanford University Press.

Jaisser, Annie. (1990). Delivering an Introduction to Psycho-Collocations with SIAB in White Hmong. Linguistics of the Tibeto-Burman Area 13: 159-178.

Matisoff, James A. 1986. Hearts and minds in South-East Asian languages and English: an essay in the comparative lexical semantics of psycho-collocation. Cahiers de Linguistique d'Asie Orientale 15(1): 5-57.

Mortensen, David. 2003. Hmong elaborate expressions are coordinate compounds. Unpublished manuscript, University of California, Berkeley.

Osada, Toshiki. 2008. Mundari. In: Anderson, Gregory D.S (ed). The Munda languages: 99164. Routledge Language Family Series 3. New York: Routledge. 
Patent, Jason D. 1998. A willy-nilly look at Lai ideophones. Linguistics of the TibetoBurman $\quad$ Area Vol. 21.1: 155-200.

Vittrant, Alice. 2014. Psycho-collocational expressives in Burmese. In: Jerey P. Williams (ed.). The Aesthetics of Grammar: Sound and Meaning in the Languages of Mainland Southeast Asia. Cambridge University Press. 